Article

\title{
Integrating Life Cycle Assessment into the Framework of Environmental Impact Assessment for Urban Systems: Framework and Case Study of Masdar City, Abu Dhabi
}

\author{
Kavya Madhu* and Stefan Pauliuk \\ Industrial Ecology Group, University of Freiburg, Tennenbacher Straße 4, 79106 Freiburg, Germany \\ * Correspondence: kavya.madhu@indecol.uni-freiburg.de
}

Received: 5 July 2019; Accepted: 3 September 2019; Published: 9 September 2019

\begin{abstract}
Planning urban expansion under the interconnected Sustainable Development Goals requires a systemic analysis of its environmental impacts. The benefits of integrating the widely used system analysis tool life cycle assessment (LCA) into the planning process tool environmental impact assessment (EIA) are described in the literature. However, not many applications of such an integration have been conducted. The aim of this study is to refine the framework for integrating LCA into the process of EIA and to apply this framework to an example of urban expansion: Masdar City in Abu Dhabi. The integrated framework builds on the complementarity between the scope and assessment steps of the tools and assesses the impacts for the areas of protection: human health, ecosystem, and resources. The framework is then applied to the vehicles, buildings, and infrastructure in the city's first development phase (DP1). Major environmental stressors include the loss of existing desert ecosystem and the utilization of non-renewable sources of energy at various development stages of DP1. Substituting natural gas-based electricity with solar power could potentially save $46 \%$ of current carbon emissions. To mitigate the land transformation impacts, construction of "close-to-nature" artificial habitats, and increased use of low-carbon fuels is suggested.
\end{abstract}

Keywords: life cycle assessment; environmental impact assessment; sustainable urban development; Masdar City

\section{Introduction}

Environmental impact assessment (EIA) is an internationally recognized planning and decision-making tool used prior to the start of construction projects in order to assess the positive and negative impacts on their immediate environment [1,2]. EIA is undertaken by following a sequential procedure that includes: (1) screening of large and medium scale projects with potentially high on-site impacts; (2) scoping: selecting impacts categories that have high site-specific environmental significance; (3) collecting baseline data on existing on-site environment; (4) predicting potential impacts of the project; assessing (5) mitigation strategies and project alternatives; (6) generating an EIA report and taking public opinion [3] (see Supplementary Material). The aim of EIA is to cover a wide range of social, biological, socio-economic, and environmental impacts of a construction project [2] and it has been introduced, in some form, in the legal development control by more than 120 nations $[1,3]$. However, it is criticized that the impact analysis in EIA relies on experience and expert judgment [1] and lacks a "defensible foundation for the evaluation of environmental impacts" [4].

Life cycle assessment (LCA) is used to quantitatively analyze the environmental impacts of a product or service throughout its life cycle [5,6] (see Supplementary Material). As such, many scientists acknowledge that a combination of EIA and LCA can be used for a comprehensive qualitative and 
quantitative assessment of large development projects, which covers not only the local impacts of a project but also the impacts along its supply chain [7-9]. It was also emphasized that LCA can be used in the procedural framework of EIA to recognize global hotspots of a project $[8,10]$, to compare project alternatives [11-14], and to comprehensively study the impacts of the whole production system of a project by analyzing its impacts during the production phase, use phase, and end-of-life phase [4]. Even though the benefits of this integration are widely recognized in the literature, its practical application remains scarce $[4,15]$. A probable reason for the aforementioned lack of practical application is that conducting an LCA study of construction projects is not a mandatory requirement drawn in the existing framework of EIA. Moreover, as LCA studies are time-intensive, they would add to the time pressure of conducting an EIA.

This paper first aims to add to the existing literature by defining a framework to integrate LCA and the systems life cycle thinking into the various steps of EIA, while keeping in mind the data availabile at the start of a project. The study then aims to apply this integrated framework to the urban development project of Masdar City, Abu Dhabi. Next to presenting the framework, the paper further focuses on the following case-specific research questions:

1. What are the major on-site and off-site impacts of construction and operation of Masdar City?

2. What are the impacts of different energy mixes used for the operation of the city on the global environment?

\section{Case Study: Masdar City}

Masdar City is a planned city initiative taken by Masdar, a subsidiary of Mubadala Development Company, in Abu Dhabi in the United Arab Emirates (UAE). Construction of Masdar City is planned in various development phases [16] covering an area of $6 \mathrm{~km}^{2}$ by 2030 [17]. Many elements of the first development phase (DP1), with an area of $1.4 \mathrm{~km}^{2}$, are now complete [18,19].

With innovative technology deployment, Masdar City aims to reduce the use of water and energy demand, total carbon emission and production of waste during its operation phase [20]. Sustainably sourced materials, such as 100\% recycled steel, $90 \%$ recycled aluminum, $100 \%$ sustainably forested timber, recycled concrete, and water-based non-volatile paint, have been used for the construction of the buildings in DP1 and these will also be used for completion of Masdar City [21].

Masdar City aims to run on $100 \%$ renewable energy on its completion instead of natural gasdominated electricity grid of UAE. To reach this goal, a $0.2 \mathrm{~km}^{2}$ photovoltaic (PV) farm and rooftop PV cells with respective capacities of $15 \mathrm{MW}$ and $1 \mathrm{MW}$ are installed that produce 17,500 MWh annually [19]. The city is also powered by a $100 \mathrm{MW}$ concentrated solar power plant (SHAMS 1) located $100 \mathrm{~km}$ from the city [22]. At present, the solar energy generated by the farms cannot completely satisfy the energy demand of DP1. Therefore, DP1 still relies on the natural gas-based energy supply from Abu Dhabi's electricity grid. Moreover, Masdar enforces a transportation scheme where gasoline vehicles are not allowed inside the city boundary. Commutes within the city are primarily by walking or biking. There is also a provision of driverless personal rapid transportation (PRT) pods and electric cars [23]. A PRT network with 100 stations has been designed but currently only two stations are working.

Masdar City is defined as an ambitious smart city project envisioned to be a zero-waste, carbon-neutral, energy positive, and sustainable urban development [24]. However, these goals were set while considering the city in isolation from its local environment and supply chains, [20] i.e., considering the impacts only within the city boundary. As the city is part of the global ecosystem and commodity supply chains, it is important to not only analyze its environmental impacts on its immediate environment, as in an EIA, but also on the global environment. Hence, Masdar City is taken as an example to apply the integration of LCA and systems perspective in the process of EIA.

\section{Materials and Methods}

EIA is used for legal development control. Therefore, to maintain the applicability and legal status of EIA, the framework described in this section follows the basic procedures of EIA and integrates the 
different LCA steps within it. This section first describes a general procedure for integrating LCA in the process of EIA and then discusses the application of this framework to Masdar City. The impacts assessed by LCA are referred to as off-site impacts as they are not site-specific, and as EIA assesses the environmental impacts of a project on its immediate environment, these impacts are referred to as on-site impacts.

\subsection{General Procedure for the Integrated Framework for Project Analysis}

The following section describes the addition of life cycle thinking and LCA, conducted in accordance to ISO standard 14040 and 14044, in process of EIA to assess and quantify the off-site impacts and the potential trade-offs of a development project throughout its life cycle. The framework makes use of an apparent symmetry in the procedural steps of EIA and LCA (Figure 1), e.g., both methods have a scoping and data inventory step. Further details of each step are provided below and in the Supplementary Material.

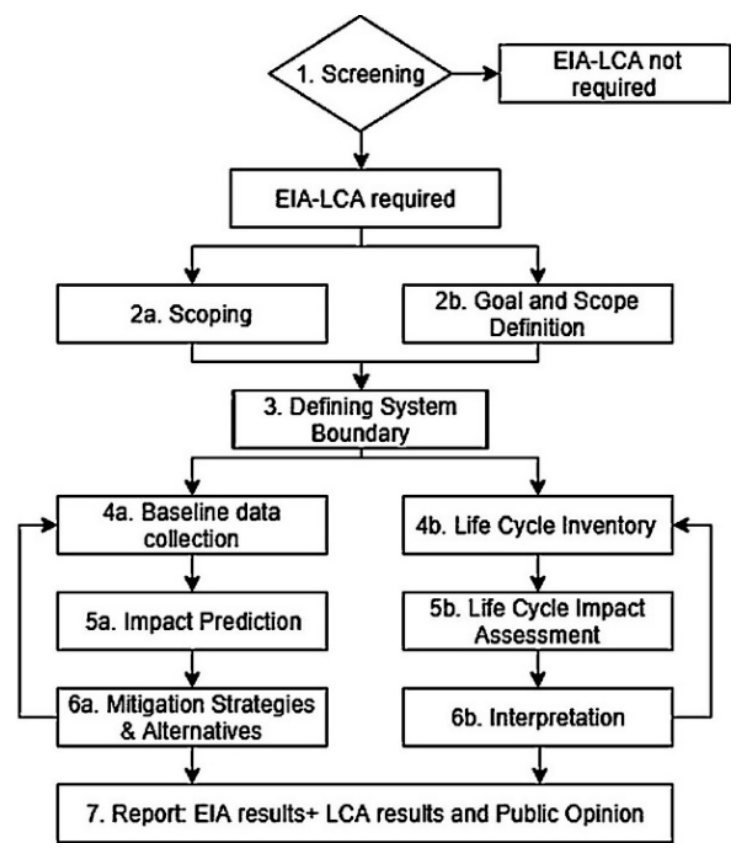

Figure 1. General framework for integrating the life cycle assessment (LCA) (right-side boxes, labeled

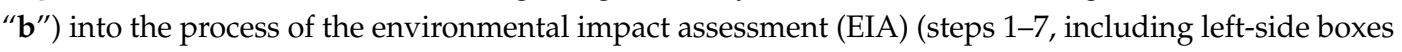
labeled " $a$ ") based on the procedural overlap between the tools. The steps $2 b$ and $4 b-6 b$ correspond to the LCA methodology, as defined in ISO standard 14040 and 14044.

1. Screening: Screening of the projects is the first step to conduct an EIA. As discussed in the earlier section, not all projects require EIA and the projects are screened based on their size and potential immediate impacts. Once the EIA screening is done, life cycle thinking is applied to the previously screened projects to determine whether an integrated EIA-LCA approach is required or not, e.g., back-of-envelope calculations of material and energy intensity of the project throughout its life cycle can be done to assist the expert judgment.

2. Scoping relevant impacts:

(a) Scoping: Scoping in EIA is done to select the significant on-site impact categories for impact prediction by conducting site surveys, literature review, studying local laws, analyzing critical habitats in and around the potential construction site, and using matrices, networks etc. to aid decision making. The relevant EIA categories are then mapped to the areas of protection: human health, environment and resources (Table 1) (details in Supplementary Material). The mapping of EIA categories to areas of protection are project-dependent and 
expert judgment is required to map them to the respective areas of protection. One impact category may be mapped to more than one area of protection.

(b) Goal and scope definition: "Scoping" or deciding on the relevant LCA functional unit and impact categories is based on the goal and scope of the LCA study. The goal is to assess relevant off-site impacts of the project to identify possible burden-shifting in space and time. The scope defines the detail in which LCA should be conducted to reach the specified goal. It also defines the functional unit, which is the quantified reference for the performance requirement of the system studied [5,6]. The mapping of LCA categories was based on the ReCiPe method of impact assessment.

3. Defining system boundary: The system boundary for the comprehensive assessment must align with the goal of the assessment and include the relevant potential impacts. The system boundary would consist of the geographical boundary of the project along with the area that would be most affected by the project development and the temporal boundary based on the life cycle stages of the project considered and the infrastructure components studied.

4. Data collection:

(a) Baseline data collection: Baseline data (i.e., data on existing environment and socio-economic condition) in EIA is collected for the selected categories mostly by site survey, chemical and biological monitoring, and desk study of available literature.

(b) Life cycle inventory phase: Data collection to conduct the LCA study is done in the life cycle inventory (LCI) phase, which gives a comprehensive account of all the inputs in the form of material, energy, and transportation requirements of the project, and outputs (i.e., emissions, by-products, co-products) from the project.

5. Impact prediction/analysis:

(a) Impact prediction: The impact categories studied in EIA are site-specific and have local importance, which are not assessed through the methods used in LCA studies e.g., ReCiPe, Eco indicator 99, CML, USEtox, etc. Impact prediction methods utilized in EIA can vary from qualitative methods, such as desk studies, site surveys, etc. to quantitative geotechnical analysis, chemical analysis, etc. [1]. The choice of method depends on the impact category studied by the EIA practitioners (see Supplementary Material).

(b) Life cycle impact assessment: Life cycle impact assessment (LCIA) is performed at both the endpoint and midpoint level to quantify the potential environmental impacts off-site. Based on the goal of the study, some impact categories must be included in the assessment. However, to account for any trade-offs and unexpected results, it is advisable to scan all potentially relevant impact categories. It is recommended to use either the Eco-indicator 99 or ReCiPe models as LCIA methods because these methods report the results of midpoint and endpoint categories in the form of the weighted and normalized single score results reported as "points" and not just in the individual units of the midpoints and endpoints. As the "points" are comparable, these are utilized to highlight most impacting midpoint categories by calculating their percentage impact from the total impact on the endpoint category (see Supplementary Material for details). The midpoint categories to the largest contribution to the total are then studied in detail, i.e., at process level, utilizing the impact assessment method $\operatorname{ReCiPe}(\mathrm{H})$, to determine the most environmentally burdensome processes associated with the project.

6. Mitigation, alternatives, and result interpretation: The mitigation strategies planned in a regular EIA aim to reduce only the impacts of a project on its immediate environment. However, in the integrated EIA-LCA framework, mitigation strategies are suggested to minimize both the on-site and off-site impacts and reduce the potential trade-offs. The environmentally burdensome processes and materials identified in the previous step were compared to their 
potential alternatives through a sensitivity analysis. A sensitivity analysis is also recommended to highlight and compare off-site impacts of different project alternatives that are investigated in a regular EIA and different future inflows in the project, etc. For example, sensitivity analysis in LCA studies can be done to compare various energy and material alternatives for construction and/or to compare future transportation scenarios, operation energy sources, etc.

7. Environmental impact report/statement and public opinion: The role of the EIA-LCA report is to provide all stakeholders a comprehensive assessment of the impacts of a project on not only its immediate environment but also throughout its life cycle. Therefore, the results of the assessment should be summarized under the various areas of protection (see: Step 2) and the life cycle phase in which the impact occurs should be explicitly stated.

Table 1. Mapping of the LCA midpoint categories, endpoint categories, and the EIA impact categories to area of protection. Source: Own study interpretation.

\begin{tabular}{cccc}
\hline Area of Protection & Human Health & Ecosystem & Resources \\
\hline LCA impact categories & $\begin{array}{c}\text { Midpoints: Human toxicity, } \\
\text { Ozone depletion, Particulate } \\
\text { matter formation .. } \\
\text { Endpoint: damage to } \\
\text { Human Health (DALY) }\end{array}$ & $\begin{array}{c}\text { Midpoints: Ecosystem } \\
\text { quality, Climate change } \\
\text { Freshwater ecotoxicty } \\
\text { Endpoint: damage to } \\
\text { Ecosystem quality (no. } \\
\text { of species lost/year) }\end{array}$ & $\begin{array}{c}\text { Midpoints: Metal depletion, } \\
\text { Fossil depletion } \\
\text { availability (increased cost to } \\
\text { access resources) }\end{array}$ \\
\hline EIA impact categories \\
& $\begin{array}{c}\text { Air quality, } \\
\text { Recreation and amenity, } \\
\text { Historic environment, } \\
\text { Visual landscape, } \\
\text { Socio-economic effect, } \\
\text { Transportation }\end{array}$ & $\begin{array}{c}\text { Terrestrial and aquatic } \\
\text { environment, } \\
\text { water and soil quality, } \\
\text { noise and vibration, } \\
\text { native flora and fauna }\end{array}$ & $\begin{array}{c}\text { Land use change, } \\
\text { water and soil (quality) } \\
\text { depletion }\end{array}$ \\
& & & \\
\hline
\end{tabular}

\subsection{Application to Masdar City}

An integrated framework of EIA and LCA was applied to the geographical boundary of DP1 of Masdar City. Different phases of city development with their components are shown in Figure 2. This section describes the integration of LCA into the process of EIA. An overview of the method is given in Table 2 and it is followed by specific details on the processes. It should be noted that the impacts of vehicles are considered in the operation phase of the city under "infrastructure".

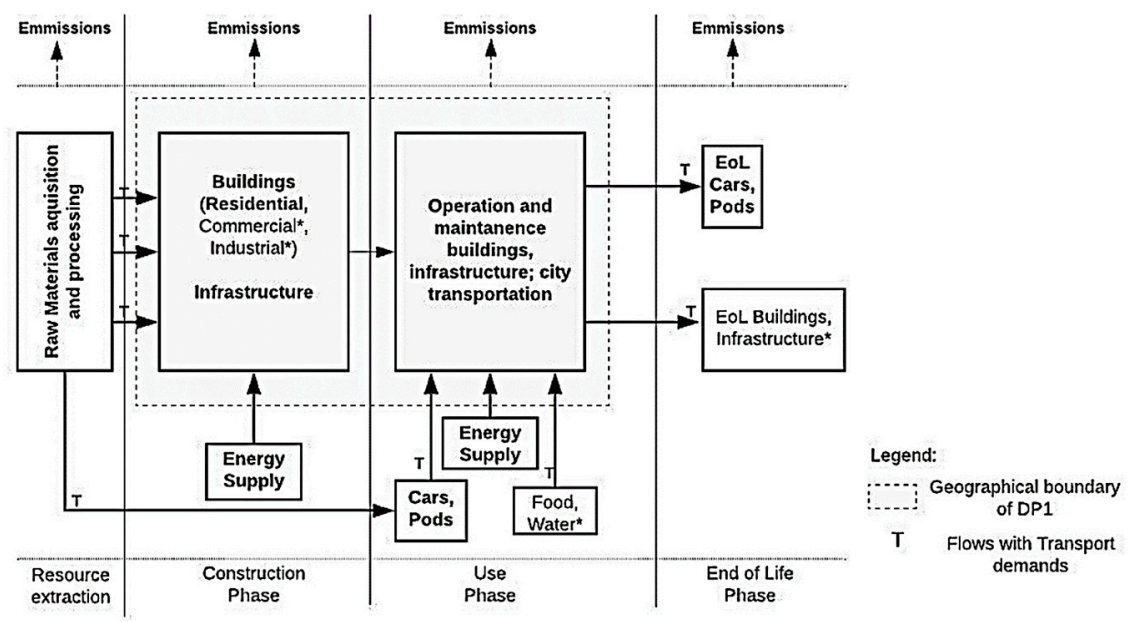

Figure 2. The system boundary for EIA-LCA framework for Masdar City as a case of new urban development. EIA evaluates the locally relevant environmental and socio-economic impacts occurring at the site (geographical boundary) of DP1. LCA accounts for the emissions occurring throughout the life cycle of the project and along its supply chain. Note: The city components with an "*" are not included in this study. 
Table 2. Application of integration of EIA and LCA framework on Masdar City (DP1). * EIA report of Masdar City [18].

\begin{tabular}{|c|c|c|}
\hline Assessment Stage & $\begin{array}{l}\text { For On-Site Impacts: EIA* } \\
\text { (Group a) }\end{array}$ & $\begin{array}{l}\text { For Off-Site Impacts: LCA } \\
\text { (Group b) }\end{array}$ \\
\hline Screening & \multicolumn{2}{|c|}{$\begin{array}{l}\text { - } \text { Masdar City DP1 has high potential impacts on immediate environment } \\
\text { - } \\
\text { - } \\
\text { - } \\
\text { - }\end{array}$} \\
\hline Scoping & $\begin{array}{l}\text { Scoping was done by } \\
\text { requirements issued by } \\
\text { Environment Agency Abu Dhabi } \\
\text { (EAD) for whole Masdar City * }\end{array}$ & $\begin{array}{l}\text { Goal and scope were defined (See } \\
\text { Section 2.2.2) and Scoping of off-site } \\
\text { impacts by ReCiPe (H/A) }\end{array}$ \\
\hline System boundary & \multicolumn{2}{|c|}{$\begin{array}{l}\text { The system boundary for the project is explicitly defined including the } \\
\text { geographical boundary, life cycle stages and different city components included in } \\
\text { the study (See Figure 2) }\end{array}$} \\
\hline Baseline data collection & $\begin{array}{l}\text { Different predefined methods } \\
\text { were used to collect and estimate } \\
\text { the existing environmental } \\
\text { conditions } \\
\text { (See Supplementary Material) }\end{array}$ & $\begin{array}{l}\text { Various literature sources were used } \\
\text { (See Supplementary Material) }\end{array}$ \\
\hline Impact prediction and significance & $\begin{array}{l}\text { Different quantitative and } \\
\text { qualitative methods; Impact } \\
\text { prediction and significance matrix } \\
\text { analysis }\end{array}$ & $\begin{array}{l}\text { - } \quad \text { LCIA at Mid-point level by } \operatorname{ReCiPe}(\mathrm{H}) \\
\text { Mid-point analysis to estimate highest } \\
\text { impacting processes by } \operatorname{ReCiPe}(\mathrm{H})\end{array}$ \\
\hline $\begin{array}{l}\text { Mitigation, alternatives and } \\
\text { interpretation }\end{array}$ & $\begin{array}{l}\text { Alternative considered in the EIA } \\
\text { report* is the alternative of "no } \\
\text { project development" }\end{array}$ & $\begin{array}{l}\text { - LCA not performed for case "no } \\
\text { project development" * } \\
\text { - Sensitivity analysis: for the current } \\
\text { and future operation energy mix } \\
\text { - Mitigation and interpretation } \\
\text { (See: Discussion) }\end{array}$ \\
\hline Environmental impact report & \multicolumn{2}{|c|}{$\begin{array}{l}\text { - Recommended section for EOL treatment of the projects } \\
\text { Impacts categories from EIA and LCA mapped under Areas of Protection } \\
\text { (See: Results) }\end{array}$} \\
\hline
\end{tabular}

\subsubsection{On-Site Impacts: EIA}

For this study, an EIA was not performed, and the on-site impacts were taken directly from the EIA report published in April 2009 for DP1 by Masdar City developers [18]. It defined the project requirements, the environmental conditions before the start of the project (referred to as the baseline environment) and significant environmental effects due to construction and the mitigation strategies during its operation phase. Desk study and a site survey were conducted as part of the EIA to gain knowledge of the baseline environment, and included existing air, water and soil quality, flora and fauna of the region, the noise level, etc. To further assess the air quality, the concentration of nitrogen oxides (NOx), particulates (PM10), benzene, carbon monoxide (CO), and dust were checked by different predefined methods. Samples of soil and water were sent for chemical analysis to evaluate their baseline constituents. Besides desk study, a noise level meter (Rion NL-32) and calibrator (Rion NL-74) were used on different sites to assess noise levels. Habitats with high conservation value were determined by site surveys and the presence or likely presence of endangered/protected species of plants or animals were investigated. Species and habitat counts were also made during the surveys to establish the significance of the effect. The detailed EIA process is given in the Supplementary Material. 


\subsubsection{Off-Site Impacts: LCA}

To calculate the off-site impacts, an LCA study in accordance with ISO standards 14040 and 14044 was done. All analysis was performed with OpenLCA (1.7.0) software and the Ecoinvent database version 3.2 with cut-off system model.

Goal and Scope Definition of LCA

The aim of the LCA study was to perform a quantitative analysis of DP1 to identify the environmentally taxing processes present in its different life cycle stages. The scope of the study includes analysis of the emissions throughout the life cycle of buildings, vehicles, and infrastructure present inside the geographic boundary of DP1. The functional unit is defined as the area of DP1 that is operated and maintained for 1 year.

\section{Life-Cycle Inventory}

To facilitate the process of LCA for DP1, it was divided into various units, namely: buildings, infrastructure, and vehicles. Buildings included in the study are the Masdar institute, IRENA headquarters, the Siemens building, the Sustainable Administrative Facility (SAF) and the Incubator building. Infrastructure in the study includes asphalt roads, concrete roads, undercroft, PRT track, parking lots for vehicles, and electric chargers for the electric cars. The vehicles included in the thesis are 12 PRT Pods and 10 Electric cars. The various life cycle phases of the product systems (city components) used in the study are shown in Table 3. In the analysis, the production of cars and pods along with their use and end of life phase was added to the operation phase of the city. The reference flows, foreground processes descriptions, and the link to the generic product life cycle inventories of Ecoinvent used to conduct the LCA study and are documented in the Supplementary Material.

Table 3. Products systems used for LCA.

\begin{tabular}{ccccc}
\hline City Components & Amount & Production Phase & $\begin{array}{c}\text { Use Phase (1 year) } \\
\text { Maintenance and } \\
\text { Operational Energy } \\
\text { (Solar) }\end{array}$ & End-of-Life Phase \\
\hline $\begin{array}{c}\text { Buildings } \\
\text { ( floors each) }\end{array}$ & $161,252 \mathrm{~m}^{2}$ per floor & Included & Included & Not included \\
\hline Infrastructure & & & Included & Not included \\
\hline Asphalt road & $7.7 \mathrm{~km}$ & Included & Included & Not included \\
\hline Concrete road & $13.3 \mathrm{~km}$ & Included & Included & Not included \\
\hline PRT pod parking & 10 units $(5 \mathrm{~m} \times 3.5 \mathrm{~m})$ & Included & Included & Not included \\
\hline Electric car Parking & $12 \mathrm{units}$ & Included & Included & Included \\
\hline Electric car Charger & $1 \mathrm{unit}(1025 \mathrm{~kg})$ & Included & Included & Not included \\
\hline Undercroft & $1.4 \mathrm{~km} \times 7 \mathrm{~m}$ & Included & Included & Not included \\
\hline PRT track & $1.4 \mathrm{~km}$ & Included & & Included \\
\hline Vehicles & & & Included & Included \\
\hline PRT Pod & $10 \mathrm{units}$ & Included & & \\
\hline Electric car & $12 \mathrm{units}$ & & & \\
\hline
\end{tabular}

Life Cycle Impact Assessment

To screen the highest impacting midpoint categories, ReCiPe (H/A) was used. To further analyze the midpoint categories at the process level, $\operatorname{ReCiPe}(\mathrm{H})$ was used. 
Mitigation, Alternatives, and Interpretation

In the EIA report, the only alternative scenario considered was a scenario with no project development. However, LCA was not performed for a "no-project" scenario. To illustrate the impact of different energy mixes for the operation of DP1, a sensitivity analysis was performed.

Sensitivity Analysis

The total installed capacity for solar energy is roughly $17,500 \mathrm{MWh} / \mathrm{yr}$ which is $37 \%$ of the approximate energy requirement of Masdar city DP1 for a year i.e., 47,200 MWh. It is assumed that the rest of the energy demand is met utilizing the national grid of UAE that's dominated by natural gas-sourced energy (Case 3). To see the impact of different energy mixes in Masdar city a sensitivity analysis was done by comparing the existing UAE energy mix (Case 1) and the current Masdar city's electricity mix (Case 3) with four probable future scenarios (Case 2, Case 4, Case 5, and Case 6) that includes addition of nuclear energy in UAE energy grid and addition of wind energy in the Masdar City energy grid. The functional unit was taken as 47,200 MWh i.e., the energy required for a year. $\operatorname{ReCiPe}(\mathrm{H})$ was used as the impact assessment method. The various scenarios considered for the sensitivity analysis that are listed below, are based on assumptions explained in the Supplementary Material along with the details on data sources. The product systems representing the scenarios include the infrastructure required for energy production and distribution but not the infrastructure required for energy storage. For this case study, emissions per capita were not evaluated because the projected future population for DP1 during the time of study was unclear.

1. Case 1 (UAE energy mix): $98 \%$ Natural gas-energy and $2 \%$ oil-energy

2. Case 2 (Solar energy scenario for Masdar city): $100 \%$ Solar energy

3. Case 3 (Current energy mix for Masdar city): Consists of $37 \%$ Solar energy and $63 \%$ of $(98 \%$ natural gas and $2 \%$ oil-energy i.e., Case 1 )

4. Case 4 (Addition of Nuclear energy in the UAE energy mix and then replacing it in Case 3): 37\% Solar energy and $63 \%$ of [ $75 \%$ of $\{(98 \%$ natural gas and $2 \%$ oil i.e., Case 1$)+25 \%$ Nuclear power $\}$ ]

5. Case 5 (Addition of wind energy in Case 2): $90 \%$ Solar energy and 10\% Wind energy

6. Case 6 (Increase of wind energy in Case 5): 50\% Solar energy and 50\% Wind energy

\section{Results}

The following sections summarize the on-site and off-site impacts of Masdar City DP1 on the three areas of protection. The off-site impacts are first reported as the total impact on midpoint categories followed by the highest impacting process in the supply chain. The on-site impacts are reported first on a scale a ranging from "slight adverse" to "beneficial" followed by the processes affecting the EIA categories.

Based on the results of ReCiPe (H/A), the following mid-point categories were found to have the highest impact on the Areas of Protection, namely, Human Health, Ecosystem and Resources:

1. Human Health: Particulate matter formation and Human toxicity for construction and operation phase, respectively.

2. Ecosystem: Climate change

3. Resources: Fossil Depletion

\subsection{Area of Protection: Human Health}

Table 4 summarizes the off-site impacts, determined under LCA impact categories and on-site impacts, determined under EIA categories of DP1 on the Area of Protection: Human Health. 
Table 4. On-site and off-site impact of the first development phase (DP1) on human health.

\begin{tabular}{|c|c|c|}
\hline & Construction Phase & Operation Phase (1 year) \\
\hline LCA Impact Category & Particulate matter formation & Human toxicity \\
\hline \multicolumn{3}{|c|}{ Buildings } \\
\hline Total emissions & $450 \mathrm{tPM}_{10} \mathrm{Eq}$ & 11,000 t 1,4-DCB-Eq \\
\hline Highest impacting process & Iron mine operation & Photovoltaic cell production \\
\hline \multicolumn{3}{|c|}{ Infrastructure } \\
\hline Total emission & $120 \mathrm{tPM}_{10} \mathrm{Eq}$ & 1400 t 1,4-DCB-Eq ${ }^{1}$ \\
\hline Highest impacting process & Clinker Production & Photovoltaic cell production \\
\hline \multicolumn{3}{|l|}{ EIA impact category } \\
\hline Noise & $\begin{array}{l}\text { Major adverse } \\
\text { Due to construction activities. } \\
\text { Expected: } 10 \text { dBA-15 dBA above } \\
60 \text { dBA upper daytime limit } \\
\text { residential area with commercial } \\
\text { activity (EAD). }\end{array}$ & $\begin{array}{l}\text { Slight Adverse } \\
\text { Noise due to change in external } \\
\text { traffic and general operations in } \\
\text { DP1. }\end{array}$ \\
\hline Air quality & $\begin{array}{l}\text { Moderate adverse } \\
\text { - } \quad \text { Due to increase in } \\
\text { vehicular traffic } \\
\text { - } \quad \text { Expected: Increase in } \\
\text { concentration of } \mathrm{NOx}, \mathrm{N} \mathrm{O}_{2} \text {, } \\
\mathrm{PM}_{10} \text {, benzene, } \mathrm{CO}\end{array}$ & $\begin{array}{l}\text { Slight adverse } \\
\text { Emissions due to increase in traffic } \\
\text { outside city boundary. }\end{array}$ \\
\hline Dust & $\begin{array}{l}\text { Major Adverse } \\
\text { Nuisance of dust due to } \\
\text { construction and vehicular } \\
\text { activity. }\end{array}$ & $\begin{array}{l}\text { Slight adverse } \\
\text { Dust due to change in external } \\
\text { traffic and general operations in } \\
\text { DP1. }\end{array}$ \\
\hline Accessibility & $\begin{array}{l}\text { Slight Adverse } \\
\text { Emissions due to construction } \\
\text { vehicles. }\end{array}$ & $\begin{array}{l}\text { Beneficial } \\
\text { Increase in accessibility due to } \\
\text { public transport. Potential } \\
\text { congestion expected }\end{array}$ \\
\hline Socio-economic & $\begin{array}{l}\text { Beneficial } \\
\text { Creation of jobs in the area. }\end{array}$ & $\begin{array}{l}\text { Beneficial } \\
\text { Create jobs, increase access to } \\
\text { improve facilities, promote } \\
\text { research and development and } \\
\text { economy }\end{array}$ \\
\hline Visual and landscape & $\begin{array}{l}\text { Major adverse } \\
\text { Landscape would be marked by } \\
\text { construction activities and vehicles }\end{array}$ & $\begin{array}{l}\text { Beneficial } \\
\text { Added urban landscape }\end{array}$ \\
\hline
\end{tabular}

Note $^{1}$ : The operation phase for infrastructure includes the production, added transportation, operation and maintenance of the electric cars and the pods. Construction and demolition of the electric cars and pods account for $2 \mathrm{t}$ 1,4-DCB-Eq and $4 \mathrm{t}$ 1,4-DCB-Eq, respectively. Operational energy required for the working of cars and pods and their maintenance for 1 year account for $0.3 \mathrm{t}$ 1,4-DCB-Eq and $37 \mathrm{t}$ 1,4-DCB-Eq, respectively. The construction and recycling do not take place inside the Masdar City boundary.

\subsection{Area of Protection: Ecosystem}

Table 5 summarizes the off-site impacts, determined under LCA impact categories and on-site impacts, determined under EIA categories of DP1 on the area of protection: ecosystem. 
Table 5. Off-site and on-site impacts of the development phase (DP) on ecosystem.

\begin{tabular}{|c|c|c|}
\hline & Construction Phase & Operation Phase (1 Year) \\
\hline \multicolumn{3}{|c|}{ LCA Impact Category: Climate Change ( $\left.\mathrm{CO}_{2}-\mathrm{Eq}\right)$} \\
\hline \multicolumn{3}{|c|}{$\begin{array}{ll} & \text { Buildings } \\
\end{array}$} \\
\hline Total emissions & 210,000 t $\mathrm{CO}_{2}-\mathrm{Eq}$ & 31,000 t $\mathrm{CO}_{2}-\mathrm{Eq}$ \\
\hline Highest impacting process & Clinker Production & Coal mine operation \\
\hline \multicolumn{3}{|c|}{ Infrastructure } \\
\hline Total emission & 88,000 t $\mathrm{CO}_{2}-\mathrm{Eq}$ & $4000 \mathrm{tCO}_{2}-\mathrm{Eq}^{2}$ \\
\hline Highest impacting process & Clinker Production & Coal mine operation \\
\hline \multicolumn{3}{|l|}{ EIA impact category } \\
\hline Ecology & Minor to Major adverse & \multirow{6}{*}{$\begin{array}{l}\text { Steps would be taken to increase } \\
\text { the biodiversity of the area. } \\
\text { However, loss of suitable desert } \\
\text { habitat is expected. } \\
\text { Artificial lighting would also affect } \\
\text { the nocturnal creatures in the area }\end{array}$} \\
\hline Habitat loss & $\begin{array}{l}\text { Major adverse } \\
\text { Clearance of } 1.4 \mathrm{~km}^{2} \text { area for } \\
\text { construction } \\
\text { Loss of native trees including Ghaf trees }\end{array}$ & \\
\hline Birds & $\begin{array}{l}\text { Minor to major adverse } \\
\text { - } \quad \text { Loss of breeding habitat } \\
\text { - } \quad \text { Destruction of nests }\end{array}$ & \\
\hline Reptiles & $\begin{array}{l}\text { Minor to moderate adverse } \\
\text { Loss/dislocation of animals }\end{array}$ & \\
\hline Mammals & $\begin{array}{l}\text { Minor to Major adverse } \\
\text { - } \quad \text { Loss of burrows } \\
\text { - } \quad \text { Loss of animals } \\
\text { - } \quad \text { Loss of feeding habitats }\end{array}$ & \\
\hline Invertebrates & $\begin{array}{l}\text { Minor to moderate adverse } \\
\text { Loss of click beetles }\end{array}$ & \\
\hline
\end{tabular}

Note $^{2}$ : The operation phase for infrastructure includes the production, added transportation, operation and maintenance of the electric cars and the pods. Construction and demolition of the electric cars and pods account for $5 \mathrm{tCO} 2-\mathrm{Eq}$ and $11 \mathrm{tCO}-\mathrm{Eq}$, respectively. Operational energy required for the working of cars and pods and their maintenance for 1 year account for 2 t CO2-Eq and $100 \mathrm{tCO}$-Eq, respectively. The construction and recycling do not take place inside the Masdar City boundary.

\subsection{Area of Protection: Resources}

Table 6 summarizes the off-site impacts, determined under LCA impact categories and on-site impacts, determined under EIA categories of DP1 on the area of protection: resources.

Table 6. On-site and off-site impact of DP1 on resources.

\begin{tabular}{ccc}
\hline & Construction Phase & Operation Phase (1 Year) \\
\hline \multicolumn{2}{c}{ LCA Impact Category: Fossil Depletion (t oil-Eq) } & \\
\hline Total emissions & 41,000 t oil-Eq & 7900 t oil-Eq \\
\hline Highest impacting process & Coal mine operation & Coal mine operation \\
\hline Total emission & Infrastructure & 1000 t oil-Eq $^{3}$ \\
\hline Highest impacting process & 14,000 t oil-Eq & Coal mine operation \\
\hline EIA impact category & Petroleum and gas production & \\
\hline
\end{tabular}


Table 6. Cont.

\begin{tabular}{|c|c|c|}
\hline & Construction Phase & Operation Phase (1 Year) \\
\hline Soil & $\begin{array}{l}\text { Minor to moderate adverse } \\
\text { - } \quad \text { Migration of offsite } \\
\text { contaminants during } \\
\text { dewatering, run-off from } \\
\text { concrete batch plant, } \\
\text { network leakage. } \\
\text { - } \quad \text { Soil reprofiling } \\
\text { - } \quad \text { Reduction of quality } \\
\text { by excavation }\end{array}$ & $\begin{array}{l}\text { Neutral } \\
\text { Possible leakage from sewage } \\
\text { network and storing and handling } \\
\text { of waste (hazardous and } \\
\text { non-hazardous). }\end{array}$ \\
\hline Ground water & $\begin{array}{l}\text { Minor to moderate adverse } \\
\text { - Dewatering affects quantity } \\
\text { of ground water } \\
\text { Local pH of groundwater } \\
\text { may change due to seepage } \\
\text { of waste from concrete } \\
\text { batch operation. }\end{array}$ & $\begin{array}{l}\text { Neutral } \\
\text { Groundwater was not extracted } \\
\text { for potable water. }\end{array}$ \\
\hline Surface water and drainage & $\begin{array}{l}\text { Minor to moderate adverse } \\
\text { - } \quad \text { Temporary use of surface } \\
\text { water for } \\
\text { construction activities. } \\
\text { Discharge of pollutants } \\
\text { in drains. }\end{array}$ & $\begin{array}{l}\text { Neutral } \\
\text { Surface water would not be a } \\
\text { source for potable water } \\
\text { Control waste discharge systems }\end{array}$ \\
\hline Man-made resources & $\begin{array}{l}\text { Neutral } \\
\text { DP1 was a barren land and none } \\
\text { of the existing in-use structures } \\
\text { were demolished. }\end{array}$ & $\begin{array}{l}\text { Beneficial } \\
\text { Addition of urban landscape }\end{array}$ \\
\hline
\end{tabular}

Note $^{3}$ : The operation phase for infrastructure includes the production, added transportation, operation and maintenance of the electric cars and the pods. Construction and demolition of the electric cars and pods account for $1 \mathrm{t}$ oil-Eq and $3 \mathrm{t}$ oil-Eq, respectively. Operational energy required for the working of cars and pods and their maintenance for 1 year account for $0.5 \mathrm{t}$ oil-Eq and $27 \mathrm{t}$ oil-Eq, respectively. The construction and recycling do not take place inside the Masdar City boundary.

\subsection{Sensitivity Analysis}

Figure 3 shows the relative impact of the six energy mix scenarios on the impact categories Climate Change $\left(\mathrm{CO}_{2}\right.$ eq), Fossil Depletion (oil eq), and Particulate matter Formation $\left(P M_{10}\right.$ eq) and the emissions in absolute numbers are shown in Table 7 (see Supplementary Material). The impact categories, climate change and fossil depletion show the same trend in ranking the six scenarios representing the different energy mixes. Case 1, representing the existing energy mix of UAE has the maximum impact on the impact categories climate change and fossil depletion while Case 2 has the minimum impact on those categories. The maximum carbon saving of $46 \%$ occurs with a shift from natural gas-based energy mix (Case 1) to a $100 \%$ solar-based energy grid (Case 2) and $63 \%$ fossil depletion is avoided with the shift. However, in the impact category Particulate matter formation, Case 2 energy scenario has the highest impact on the category while Case 1 has the lowest. Comparing the current energy mix (Case 3) with Case 2 and the two future scenarios with a fraction of wind-based energy (Case 5 and Case 6) highlights that a shift from Case 3 to Case 2, Case 5, and Case 6 would save approximately 29\%,29\%, and $26 \% \mathrm{CO}_{2}$ emissions, respectively. However, converting the current energy mix of Masdar City DP1 (Case 3) to Case 6 instead of Case 2 would also save 22\% particulate matter emissions. In all the categories, the impact of Case 4 is lower than Case 3. 


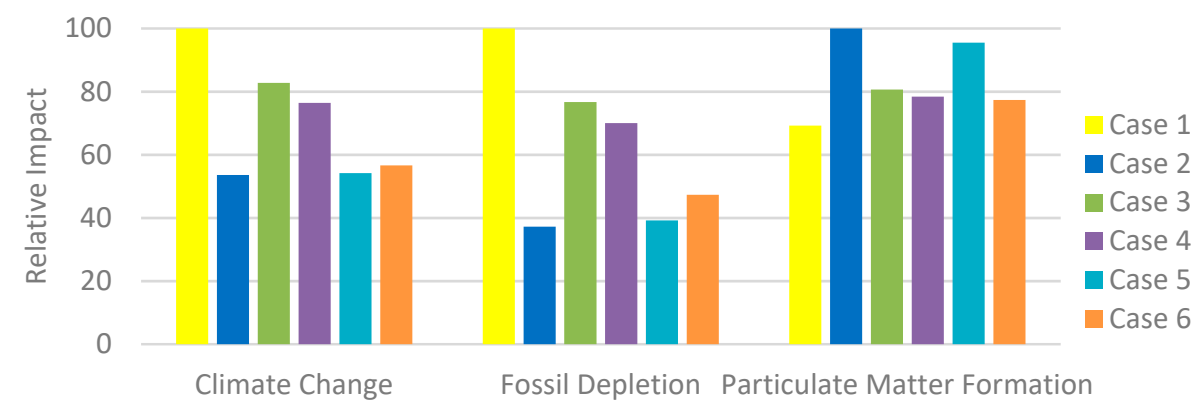

Figure 3. Sensitivity analysis of the six scenarios defined for the energy mixes of DP1. The scenario with the highest impact was taken as $100 \%$ and the rest of the scenarios are relative to it.

Table 7. Impact of the scenarios on the mid-point categories climate change, fossil depletion, and particulate matter formation.

\begin{tabular}{ccccccc}
\hline Impact Category & Case $\mathbf{1}$ & Case 2 & Case 3 & Case 4 & Case 5 & Case 6 \\
\hline Climate Change $(\mathrm{t} \mathrm{CO}$-Eq) & 63,000 & 34,000 & 52,000 & 48,000 & 34,000 & 36,000 \\
\hline Fossil Depletion $(\mathrm{t}$ oil-Eq) & 25,000 & 9300 & 19,000 & 18,000 & 10,000 & 12,000 \\
\hline Particulate Matter Formation $\left(\mathrm{t} \mathrm{PM}_{10} \mathrm{Eq}\right)$ & 70 & 100 & 83 & 81 & 100 & 80 \\
\hline
\end{tabular}

\section{Discussion}

This research supports previous studies $[7,10]$ that discussed the benefits of integrating LCA and EIA to aid sustainable urban development and to decrease the subjectivity of the EIA process. This section highlights the case study specific research findings and recommendations to the city developers followed by the general application of the framework along, with its limitations and scope for improvement.

\subsection{Case Study Results}

Lenzen et al. [11] and Rybaczewska et al. [4] discussed the importance of including the upstream and downstream impacts of a project in an EIA as these impacts could have more adverse impacts on the environment than the project's operation phase. The results in this study are in line with their findings.

Integration of LCA and EIA highlights many on-site and off-site impacts associated with the construction and operation of Masdar City DP1 (Tables 4-6). As reported in the EIA report of DP1 [18], the on-site environmental impacts associated with DP1 are not severe or permanent due to the mitigation strategies planned by the city developers. The severity of impacts depend on the value of resources and the state of the impact, i.e., whether it is permanent or temporary. Therefore, loss of species, loss of habitats, and increase in vehicular congestion are classified as residual but not severe impacts in the EIA report [18]. Besides environmental impacts, positive impacts on people's lifestyles including increases in jobs and commuting convenience are also highlighted in the EIA report [18].

However, the off-site emissions to meet the energy and the material demand to develop Masdar City DP1 affect some globally important mid-point categories like climate change, particulate matter formation and fossil depletion due to the release of 300,000 t of CO2 Eq, $600 \mathrm{t}$ of PM10 Eq, and depletion of $650,000 \mathrm{t}$ oil Eq. The off-site impacts during the construction phase of DP1 are mainly due to high demand for iron and cement to develop the infrastructure and buildings of DP1 specifically impacting the mid-point categories: climate change and particulate matter formation. Additionally, the use of non-renewable energy sources (oil-based or coal-based) for the construction of DP1 and in the supply chain of various raw materials is a major environmental stressor.

Furthermore, for the operation of DP1 it was assumed that solar energy is used. Even though solar cells provide clean energy compared to the existing gas-based energy supply in Abu Dhabi, still, 
their human toxicity impact is $12,000 \mathrm{t} 1,4$-DCB-Eq, which mainly results from the production of solar cells. The other major process that negatively affects the environment during the operation phase is coal mine operation. The material intensity assumed for building and infrastructure maintenance ranged from $1 \%-10 \%$. Therefore, the impacts due to coal mine operation can be apportioned to the supply chain of the electric cars, pods, and solar cells.

The sensitivity analysis (Figure 3 and Table 7), shows that instead of using the current UAE natural gas-based energy (Case 1) for the operation phase of DP1, using the modified UAE grid (Case 4) or further increase of solar energy (Case 2 and Case 5) and wind energy (Case 5 and Case 6) would have a positive impact on the midpoint categories climate change and fossil depletion but a negative impact on the category particulate matter formation. The increase in particulate matter due to the increase of nuclear energy, solar energy, and wind energy is due to the background data in Ecoinvent database that allocates the particulate matter emissions to the supply chains involved in the production of infrastructure of these technologies. In particular, the use of lignite-based energy in solar panel manufacturing and the use of oil-based energy for manufacturing the assets for wind-based and nuclear-based energy. The analysis further shows the importance of having different sources of energy in an energy mix because energy mix dominated by one source of energy (e.g., Case 1 or Case 2) may perform the best in once impact category but worst in the others either due to emissions in the use phase or the intensive infrastructure requirements. A comparison of Case 2 (100\% solar energy) with Case 6 that includes 50\% wind energy, respectively, highlights that even though Case 2 would save $46 \%$ carbon emissions w.r.t Case 1, inclusion of wind energy will not only save $43 \%$ carbon emissions w.r.t Case 1 but also 23\% particulate matter w.r.t Case 2. The carbon emission along with the particulate matter emission from the current DP1 energy grid (Case 3) would reduce with the addition of nuclear energy into the energy grid of UAE (Case 4).

It must be emphasized that the assumptions made to conduct the LCA lead to uncertainty in the assessment. Hence, even though the results give some interesting insights into the development and operation of DP1 of Masdar City, the results are highly dependent on the assumptions made and should be interpreted with caution.

\subsection{Recommendations for Masdar City Developers}

Mitigation strategies planned by the city developers of Masdar City are focused on minimizing the environmental impacts of DP1 on its immediate environment. As mentioned in the EIA report [18], construction of "close-to-nature" artificial habitats to compensate for the ecological loss, continuous groundwater and air monitoring, and construction of waste consolidation areas are some of the measures planned by the city developers to minimize the on-site impacts. It is further recommended to use a simplified LCA during the material procurement process to include the transportation distance from the source to the construction site, and the possible end of life treatment of the same. However, with an overview of the off-site impacts, use of secondary materials and recycled concrete aggregates are recommended for the further development of Masdar City. Introducing other sources of renewable energy in the planned energy mix of Masdar City is also recommended for its operation in order to not only reduce the carbon emission but also particulate matter emissions. Moreover, the studies [25,26] have shown a positive environmental impact of using secondary material. Therefore, we recommend the use of larger quantities of secondary material—if available in sufficiently high quality-in the further development of Masdar City. We also recommend recycling or, even better, the re-use of the structural components at the end-of-life of buildings and infrastructure instead of the widely used practice of landfilling or incineration."

\subsection{The Framework: Role of LCA, Strengths, and Applicability}

In the discussed framework, LCA has been integrated at different steps in the process of EIA to serve different goals. Firstly, LCA serves as a quantitative analysis tool when used to compare various raw materials or project alternatives, and this quantitative analysis helps to identify the hotspots in 
different supply chains. This application of LCA aids the project developers in making an informed decision, regarding possible raw materials, process choices or project alternatives, by considering their life cycle emissions. Secondly, LCA widens the scope of the assessment when compared to a conventional EIA as it quantitatively evaluates the environmental impact of a project throughout its lifetime. Thus, through quantitative analysis, the method combination allows for the identification of trade-offs between on-site and off-site impacts.

There are four strengths of the framework that are worth discussing. Firstly, as the main aim behind the framework is to support sustainable urban development, it is important that the results from the integrated approach are conveyed well and easy to understand by the stakeholders. Therefore, as shown in Table 1, the results of LCA and EIA studied under the three areas of protection include impacts of both global and local importance and provide a comprehensive picture of the on-site and off-site impacts. Secondly, the other benefit that integrated the EIA-LCA approach has over the common methods used for sustainability assessment of the regions (e.g., material flow analysis (MFA), city carbon footprint, water footprint, etc. [27]) is the inclusion of intangible aspects of the region like socio-economic aspects, cultural aspects, etc. into the assessment. Thirdly, conventional EIA reports do not address the demolition of the project. Hence, the inclusion of life cycle thinking for project demolition phase of the project further drives the project in a sustainable direction. Fourthly, the proposed framework adds the possibility to do sensitivity analysis to consider the impacts for variable inflows into the project like comparing different electricity mixes, vehicles, etc.

The application of the framework on different infrastructural systems of DP1 demonstrates that the framework can be applied to not only a development project or part of a project (e.g., infrastructure) but also at an aggregated regional level.

\subsection{Limitations of the Study and the Framework and Future Method Development}

The limitations of the LCA conducted in the study arise due to the lack of data and the assumptions made to do the assessment. This adds to the inherent uncertainty of the LCA methodology. Moreover, in the study only one variable input to the city i.e., the different energy mixes are considered. However, water use, food supply, waste management, communication infrastructure, etc. also have an impact on the overall sustainability of a city or a project.

The limitation of this framework lies in the fact that both LCA and EIA are time- and data-intensive methods. The integration of these methods requires additional time, data, and expertise than a regular EIA, which may hinder the practical applicability of this framework. However, with increases in the number of processes and products in the LCA databases, practicing strict scoping mechanisms, and the inclusion of timeframes for each step can help control the added cost and time. The results from the framework are sensitive to the system boundary defined by the practitioners in Step 3, which with slight manipulation may lead to favorable results for the project developers. This challenge can be overcome by defining appropriate and reasonable geographical, temporal, and LCA system boundaries and explicitly mentioning those in the EIA report.

The suggested method in this paper defines an approach to integrate systemic thinking and LCA into the framework of EIA and the EIA report for sustainable urban development projects. Further studies are needed to refine the methodology and apply it to different infrastructural projects, including water, waste, and food networks.

\section{Conclusions}

This study has successfully outlined a framework to integrate LCA in various steps of EIA, which is applicable to not only large scale or medium scale development projects but also to geographically defined regions. Even though this framework is time- and data-intensive, it can be utilized to assess various environmental, social, and economic impacts of both local and global importance. The framework can aid decision-makers during procurement of raw materials, comparison between various 
alternatives of a project, site analysis for projects, comparing various technologies, and planning the decommissioning of the project for enhanced material recovery.

Supplementary Materials: The following are available online at http://www.mdpi.com/2076-3298/6/9/105/s1. Figure S1: Basic steps followed in LCA, Table S1: Different categories of project based on their size, Table S2: Procedure to conduct an EIA, Table S3: Impact Categories assessed by EIA for DP1, Tables S.A-S.I: Details on material intensities used in LCA for Pedestrian pathway, undercroft, PRT parking, Asphalt road, electric car parking, maintenance for electric car parking and asphalt road, PRT pod, buildings and operation energy respectively, Table S4: Product Systems used for sensitivity analysis, Table S5: Results for sensitivity analysis, Table S6: Product system and processes used for LCA analysis.

Author Contributions: Conceptualization, K.M. and S.P.; data curation, K.M.; formal analysis, K.M.; investigation, K.M.; methodology, K.M.; supervision, S.P.; visualization, K.M. and S.P.; writing-original draft, K.M.; writing-review and editing, K.M. and S.P.

Funding: No funding was received to carry out the study.

Acknowledgments: We acknowledge the developers of Masdar City for providing the EIA report. The article processing charge was funded by the German Research Foundation (DFG) and the University of Freiburg in the funding program Open Access Publishing and we acknowledge their support.

Conflicts of Interest: The authors declare no conflict of interest.

\section{References}

1. Glasson, J.; Therivel, R.; Chadwick, A. Introduction to Environmental Impact Assessment: Principles and Procedures, Process, Practice, and Prospects, 2nd ed.; UCL Press: London, UK, 1999.

2. Department of Conservation, New Zealand. The Guide to Preparing Your Environmental Impact Assessment (EIA) for Concessions Applications. Available online: https:/www.doc.govt.nz/get-involved/apply-forpermits/managing-your-concession/environmental-impact-assessment/ (accessed on 9 September 2019).

3. Environmental Protection Agency. Guidelines on the Information to Be Contained in Environmental Impact Statements; Environmental Protection Agency: Wexford, Ireland, 2002.

4. Rybaczewska-Blażejowska, M.; Palekhov, D. Life Cycle Assessment (LCA) in Environmental Impact Assessment (EIA): Principles and practical implications for industrial projects. Management 2018, 22, $138-153$. [CrossRef]

5. ISO. ISO (14040:2006): Environmental Management-Life Cycle Assessment-Principles and Framework; International Organization for Standardization: Geneva, Switzerland, 2006.

6. ISO. ISO (14044:2006): Environmental Management-Life Cycle Assessment-Requirements and Guidelines; International Organization for Standardization: Geneva, Switzerland, 2006.

7. Tukker, A. Life cycle assessment as a tool in environmental impact assessment. Environ. Impact Assess. Rev. 2000, 20, 435-456. [CrossRef]

8. Židonienè, S.; Kruopienè, J. Life Cycle Assessment in environmental impact assessments of industrial projects: Towards the improvement. J. Clean. Prod. 2015, 106, 533-540. [CrossRef]

9. Jeswani, H.K.; Azapagic, A.; Schepelmann, P.; Ritthoff, M. Options for broadening and deepening the LCA approaches. J. Clean. Prod. 2010, 18, 120-127. [CrossRef]

10. Larrey-Lassalle, P.; Catel, L.; Roux, P.; Rosenbaum, R.K.; Lopez-Ferber, M.; Junqua, G.; Loiseau, E. An innovative implementation of LCA within the EIA procedure: Lessons learned from two Wastewater Treatment Plant case studies. Environ. Impact Assess. Rev. 2017, 63, 95-106. [CrossRef]

11. Lenzen, M.; Murray, S.A.; Korte, B.; Dey, C.J. Environmental impact assessment including indirect effects-A case study using input-output analysis. Environ. Impact Assess. Rev. 2003, 23, 263-282. [CrossRef]

12. Steinemann, A. Improving alternatives for environmental impact assessment. Environ. Impact Assess. Rev. 2001, 21, 3-21. [CrossRef]

13. Manuilova, A.; Suebsiri, J.; Wilson, M. Should Life Cycle Assessment be part of the Environmental Impact Assessment? Case study: EIA of $\mathrm{CO}_{2}$ Capture and Storage in Canada. Energy Procedia 2009, 1, 4511-4518. [CrossRef]

14. Cornejo, F.; Janssen, M.J.M.; Gaudreault, C.; Samson, R.; Stuart, P.R. Using Life Cycle Assessment (LCA) as a tool to enhance Environmental Impact Assessment (EIA). In Proceedings of the 8th Conference on Process 
Integration Modeling and Opitmization for Energy Saving and Pollution Reduction-PRES: Italy, 15-18 May 2005; Volume 5, pp. 521-528.

15. Bidstrup, M. Life cycle thinking in impact assessment-Current practice and LCA gains. Environ. Impact Assess. Rev. 2015, 54, 72-79. [CrossRef]

16. Aidan Imanova. Masdar City Targets Completion by 2030. Available online: https://www.arabianbusiness. com/masdar-city-targets-completion-by-2030-639109.html (accessed on 2 January 2019).

17. Bernhard Schulz. Auf der Sonnenseite der Moderne. Available online: https://www.tagesspiegel.de/ wirtschaft/immobilien/was-wurde-aus-der-zukunftsstadt-masdar-city-auf-der-sonnenseite-der-moderne/ 20658020.html/ (accessed on 2 January 2019).

18. Masdar City Authorities and Hyder Consulting Middle East Ltd. Environmental Impact Assessment Report Masdar Delivery Phase 1: Report Number: 10-AU00443-F-R V3; Masdar City Authorities: Masdar City, Abu Dhabi, 2009.

19. Masdar-City. The City. Available online: https://masdar.ae/en/masdar-city/the-city (accessed on 2 January 2019).

20. Goldenberg, S. Masdar's Zero-Carbon Dream could Become World's First Green Ghost Town. The Guardian, 16 February 2016.

21. Manghnani, N.; Bajaj, K. Masdar City: A Model of Urban Environmental Sustainability. Int. J. Eng. Res. Appl. 2014, 4, 38-42.

22. Lee, S.E.; Braithwaite, P.; Leach, J.M.; Rogers, C.D. A comparison of energy systems in Birmingham, UK, with Masdar City, an embryonic city in Abu Dhabi Emirate. Renew. Sustain. Energy Rev. 2016, 65, 1299-1309. [CrossRef]

23. Masdar City at a Glance. Available online: Http://www.masdar.ae/en/masdar-city/detail/masdar-city-at-aglance (accessed on 30 October 2017).

24. Arthur de Villemandy. Masdar Showcases the Concept of the Smart City-L'Atelier BNP Paribas. Available online: https://atelier.bnpparibas/en/smart-city/article/masdar-showcases-concept-smart-city (accessed on 2 January 2019).

25. Zygomalas, I.; Baniotopoulos, C. Environmental impact assessment of end-of-life scenarios for steel buildings. Eur. J. Environ. Civ. Eng. 2016, 20, 301-313. [CrossRef]

26. Hradil, P.; Talja, A.; Wahlström, M.; Huuhka, S.; Lahdensivu, J.; Pikkuvirta, J. Re-Use of Structural Elements; Environmentally Efficient Recovery of Building Components: VTT Technical Research Centre of Finland; Julkaisija Utgivare Publisher: Helsinki, Finland, 2014.

27. Mirabella, N.; Allacker, K. The Assessment of Urban Environmental Impacts through the City Environmental Footprint: Methodological Framework and First Approach to the Built Environment. Procedia CIRP 2018, 69, 83-88. [CrossRef]

(C) 2019 by the authors. Licensee MDPI, Basel, Switzerland. This article is an open access article distributed under the terms and conditions of the Creative Commons Attribution (CC BY) license (http://creativecommons.org/licenses/by/4.0/). 